\title{
MENINGKATKAN KETERAMPILAN SISWA DALAM MENYELESAIKAN SOAL CERITA PADA SISTEM PERSAMAAN LINEAR DUA VARIABEL MELALUI PENGGUNAAN LANGKAH POLYA
}

\author{
NARLIAH \\ SMP Negeri 02 Rumbia \\ e-mail : narliahajha@gmail.com
}

\begin{abstract}
ABSTRAK
Pembelajaran efektif adalah pembelajaran yang mampu mengubah perilaku peserta didik yang meliputi pengetahuan, penalaran, kecakapan dan kebiasaan. Pembelajaran matematika di sekolah mengemban tercapainya dua sasaran yaitu (1) terbentuknya karakter peserta didik yang logis, kritis, rasional, cermat, efektif dan efisien dan (2) implementasi hasil dalam kehidupan sehari- hari dan pengembangan ilmu pengetahuan. Menurut pengamatan penulis sebagai guru matematika di SMP ini, sebagian besar siswa kelas VIII tidak dapat menyelesaikan soal cerita dengan benar. Di samping itu penyelenggaraan ujian baik itu berupa Asessmen kompetensi nasional maupun ujian sekolah yang menggunakan soal pilihan ganda dapat merangsang siswa untuk menyelesaikan dengan jalan pintas. Hal ini menyebabkan siswa semakin sulit mengerjakan soal-soal cerita yang menantang dan menuntut pemikiran lebih tinggi. Untuk meningkatkan keterampilan siswa dalam menyelesaikan soal cerita perlu ditekankan penggunaan langkah prosedural sebagaimana dianjurkan oleh George Polya yaitu memahami masalah, menyusun rencana penyelesaian, melaksanakan rencana penyelesaian dan memeriksa hasil yang diperoleh. Penelitian ini terlaksana dalam dua siklus. Pada siklus I diperoleh hasil bahwa keterampilan siswa dalam menyelesaikan soal cerita Sistem Persamaan Linear Dua Variabel belum maksimal. Persentase keterampilan mencapai $45 \%$ dan ketuntasan belajar mencapai $40 \%$. Pada siklus II setelah dilakukan refleksi dan pembenahan, diperoleh hasil persentase keterampilan sebesar $75 \%$ sedangkan ketuntasan belajar mencapai $76 \%$. Dengan demikian keterampilan siswa meningkat $30 \%$ dan ketuntasan belajar meningkat $36 \%$. Dari penelitian ini diperoleh simpulan bahwa melalui penggunaan langkah Polya, keterampilan siswa kelas VIII C SMP Negeri 02 Rumbia Tahun Pelajaran 2020/2021 dalam menyelesaikan soal cerita sistem persamaan linear dua variabel dapat ditingkatkan. Akhirnya penulis menyarankan kepada guru matematika kelas VIII SMP Negeri 02 Rumbia untuk dapat menggunakan langkah Polya dalam pembelajaran berkaitan dengan soal cerita sehingga siswa dapat menyelesikan soal secara sistematis.
\end{abstract}

Kata Kunci : SPLDV, Penggunaan Langkah Polya, Penelitian Tindakan Kelas

\section{ABSTRACT}

Effective learning is learning that is able to change the behavior of students which includes knowledge, reasoning, skills and habits. Mathematics learning in schools has two goals, namely (1) the formation of students' characters who are logical, critical, rational, careful, effective and efficient and (2) the implementation of the results in everyday life and the development of science. According to the author's observations as a mathematics teacher at this junior high school, most of the eighth grade students cannot solve story problems correctly. In addition, the administration of exams, whether in the form of a national competency assessment or school exams using multiple choice questions, can stimulate students to complete with shortcuts. This causes students to find it increasingly difficult to work on story questions that are challenging and require higher thinking. To improve students' skills in solving story problems, it is necessary to emphasize the use of procedural steps as recommended by George Polya, namely understanding the problem, compiling a settlement plan, implementing a settlement plan and checking the results obtained. This research was carried out in two cycles. In the first cycle, it was found that the students' skills in solving the story problems of the Two Variable Linear Equation System were not maximized. The percentage of skills reaches $45 \%$ and completeness 
of learning reaches $40 \%$. In the second cycle after reflection and improvement, the percentage of skills obtained is $75 \%$ while learning completeness reaches $76 \%$. Thus, students' skills increased by $30 \%$ and learning completeness increased by $36 \%$. From this study, it was concluded that through the use of the Polya step, the skills of class VIII C students of SMP Negeri 02 Rumbia in the 2020/2021 academic year in solving story problems of a two-variable linear equation system could be improved. Finally, the author suggests the VIII grade math teacher at SMP Negeri 02 Rumbia to be able to use Polya's steps in learning related to story problems so that students can solve problems systematically.

Keywords: SPLDV, Polya Step Use, Classroom Action Research

\section{PENDAHULUAN}

Matematika merupakan ilmu universal yang mendasari perkembangan teknologi modern mempunyai peran penting dalam berbagai disiplin dan memajukan daya pikir manusia. Mata pelajaran Matematika sangat bermanfaat dalam kehidupan, diberikan kepada semua peserta didik dari sekolah dasar untuk membekali kemampuan berpikir logis, analitis, sistematis, kritis dan kreatif serta kemampuan bekerja sama. Kompetensi tersebut diperlukan agar peserta didik dapat memiliki kemampuan memperoleh, mengelola dan memanfaatkan informasi untuk bertahan hidup pada keadaan yang selalu berubah, tidak pasti dan kompetitif. Sebagian besar ahli pendidikan matematika menyatakan bahwa masalah adalah pertanyaan yang harus dijawab/direspon. Namun tidak semua pertanyaan otomatis menjadi masalah. Suatu pertanyaan akan menjadi masalah hanya jika pertanyaan itu menunjukkan suatu tantangan (challange) yang tidak dapat dipecahkan oleh suatu prosedur rutin (routine procedure) yang sudah diketahui siswa. Dari definisi tersebut dapat terjadi bahwa suatu pertanyaan yang merupakan masalah bagi seseorang siswa akan menjadi pertanyaan biasa bagi siswa lainnya karena ia telah mengetahui prosedur untuk menyelesaikannya (Shadiq, Fadjar, 2004:10).

Sebagai guru matematika yang telah lama mengajar di SMP Negeri 02 Rumbia menyadari bahwa dengan input yang kurang berkualitas sangat berpengaruh terhadap hasil yang akan dicapai. Pada umumnya sebagian besar siswa menganggap bahwa matematika merupakan mata pelajaran yang sulit dibanding mata pelajaran lainnya. Terbukti pada setiap pembahasan soal yang menyangkut kehidupan sehari- hari, terlebih soal yang tersaji dalam bentuk cerita maka sebagian besar siswa tidak dapat menyelesaikan secara benar. Hal ini disebabkan karena siswa tidak memahami maksud soal, lemah dalam penguasaan bahasa atau belum mengetahui prosedur rutin yang seharusnya digunakan untuk menyelesaikan soal tersebut. Utari, et.al (dalam Supangih dkk, 2018) mengemukakan bahwa matematika merupakan suatu mata pelajaran yang memiliki peranan cukup penting, baik dalam kehidupan sehari-hari maupun untuk membantu siswa mengkaji sesuatu secara logis, kreatif dan sistematis. Oleh karena itu, pembelajaran matematika harus mengutamakan untuk berpikir sistematis, kritis dan kemampuan pemecahan masalah. Ruseffendi (2006) mengemukakan bahwa kemampuan pemecahan masalah amat penting dalam matematika, bukan saja bagi mereka yang kemudian hari untuk mendalami atau mempelajari matematika, melainkan juga bagi mereka yang akan menerapkannya dalam bidang studi lain dan dalam kehidupan seharihari. Kelemahan dalam memecahkan masalah siswa adalah lemahnya dalam menganalisis soal, memonitor proses penyelesaian, dan mengevaluasi hasilnya Sabirin (2011).

Menurut Polya (dalam Wibisono, 2019) telah menyajikan teknik-teknik pemecahan masalah yang tidak hanya menarik tetapi juga dimaksudkan untuk meyakinkan bahwa prinsipprinsip yang dipelajari selama belajar matematika akan ditransfer seluas-luasnya.

Penulis mengangkat materi pokok Sistem Persamaan Linear Dua Variabel karena dalam materi pokok ini memuat banyak permasalahan menyangkut kehidupan sehari-hari yang tertuang dalam soal cerita dan termasuk dalam kajian semester gasal yang harus disampaikan kepada siswa. Kenyataan yang penulis temukan adalah hampir sebagian besar siswa kelas VIII tidak dapat menyelesaikan soal cerita dengan benar. Seperti pada pelaksanaan Asessmen Kompetensi Nasional yang belum lama ini mereka lakukan sebagian besar siswa mengalami 
kendala pengerjaan soal numerasi. Pada umumnya siswa menyelesaikan soal cerita dengan langkah- langkah yang tidak urut/tidak sistematis. Dalam hal ini tidak hanya keterampilan saja yang diperlukan, namun dibutuhkan kemampuan lain seperti menggunakan algoritma tertentu dan penalaran matematika.

Dengan demikian pemecahan masalah/soal cerita dengan menggunakan langkah sistematis sebagaimana dianjurkan oleh George Polya dipandang sangat efektif dan esensial diberikan kepada siswa sehingga mereka terlatih dalam menyelesaikan permasalahan, mampu menyeleksi informasi yang relevan, menganalisis dan akhirnya mampu merefleksi kembali kebenaran hasil yang telah dicapai. Berdasarkan 4 tahapan pemecahan masalah Polya tersebut, Herlambang (2013) mengklasifikasikan 4 tingkatan kemampuan siswa dalam menyelesaikan soal permasalahan sebagai berikut. "(1) Subjek tidak mampu melaksanakan 4 langkah pemecahan masalah Polya; (2) Subjek mampu memahami masalah; (3) Subjek mampu melaksanakan tahap memahami masalah, tahapan menyusun rencana penyelesaian, dan tahap melaksanakan rencana penyelesaian; (4) Subjek mampu melaksanakan tahap memahami soal, menyusun rencana penyelesaian, melaksanakan rencana penyelesaian, dan tahap memeriksa kembali”. Dengan menguasai langkah- langkah Polya dalam pemecahan masalah, diharapkan siswa terampil menyelesaikan permasalahan terkait soal-soal cerita. Adapun tujuan penelitian adalah untuk mengetahui peningkatan keterampilan siswa kelas VIII C SMP Negeri 02 Rumbia dalam menyelesaikan soal cerita pada Sistem Persamaan Linear Dua Variabel melalui penggunaan langkah Polya, sedangkan rumusan permasalahan dalam penelitian ini "Apakah melalui penggunaan langkah Polya dapat meningkatkan keterampilan siswa kelas VIII C SMP Negeri 02 Rumbia Tahun Pelajaran 2020/2021 dalam menyelesaikan soal cerita pada Sistem Persamaan Linear Dua Variabel?"

\section{METODE PENELITIAN}

Penelitian ini dilaksanakan di SMP Negeri 02 Rumbia dengan subjek penelitian adalah seluruh siswa kelas VIII C yang terdiri dari 13 siswa puteri dan 12 siswa putera. Prosedur penelitian ini dilaksanakan dalam 2 siklus, masing-masing siklus terdiri dari empat tahapan yaitu perencanaan, pelaksanaan tindakan, pengamatan dan refleksi. Jenis data yang digunakan dalam penelitian ini adalah tes hasil belajar siswa pada materi ajar Persamaan Linear Dua Variabel, dan lembar observasi siswa yang memuat pengamatan kegiatan siswa dalam proses pembelajaran. Sedangkan indikator keberhasilan dalam penelitian ini ingin mengungkap tingkat keterampilan siswa dalam menyelesaikan soal cerita pada sistem persaman linear dua variabel melalui penggunaan langkah Polya.

Secara lebih rinci menurut Nur, (2019: 34) kategori tingkat keterampilan atau kemampuan pemecahan masalah siswa sebagai berikut :

Tabel 1. Kategorisasi menyelesaikan soal cerita Matematika

\begin{tabular}{|c|c|c|}
\hline Rentang & Nilai Akhir Siswa & Kategori \\
\hline $16,8-22$ & $76,3-100$ & Sangat baik \\
$11,2-16,7$ & $50,9-75$ & Baik \\
$5,6-11,1$ & $25,45-50$ & Cukup \\
$0-5,5$ & $0-25$ & Kurang baik \\
\hline
\end{tabular}

Tingkat kemampuan dan keterampilan siswa dalam menyelesaikan soal dikatakan baik apabila skor yang diperoleh siswa melalui tes berada pada tingkat kemampuan dan keterampilan berkategori baik dan minimal 75\% dari jumlah siswa mencapai nilai KKM 65 .

\section{HASIL DAN PEMBAHASAN}

\section{A. Hasil Penelitian}

Tujuan dari penelitian ini untuk mengetahui peningkatan keterampilan siswa dalam menyelesaikan soal-soal cerita pada materi pembelajaran Sistem Persamaan Linear Dua Variabel melalui penggunaan langkah Polya. Penulis adah guru yang mengampu mata pelajaran 
matematika di kelas VIII.C sehingga memahami karakterikstik siswa, menurut obeservasi penulis hampir sebagian besar siswa tidak dapat menyelesaikan soal-soal cerita kontekstual, sementara pada banyak dijumpai soal-soal serupa pada materi ajar sistem persamaan linear dua variabel, seperti pada kegiatan Ujian sekolah maupun Nasional banyak ditemukan soal-soal cerita, dan pada umumnya para siswa cepat menyerah, kurang tertantang, tidak memahami maksud kalimat soal.

Sebelum pelaksanaan siklus 1, penulis memberikan tes kepada siswa untuk mengetahui tingkat keterampilan siswa menyelesaikan soal sebelum menggunakan langkah POLYA, dan hasilnya ditunjukkan pada tabel berikut :

Tabel 2. Tingkat Keterampilan Siswa sebelum tindakan

\begin{tabular}{|c|c|c|c|c|}
\hline No. Soal & $\begin{array}{c}\text { Alokasi } \\
\text { Waktu }\end{array}$ & Banyak siswa & Persentase & Keterangan \\
\hline \multirow{3}{*}{1} & $\mathrm{~A}$ & 5 & 20 & A : $\square$ 10 menit \\
\cline { 2 - 5 } & $\mathrm{B}$ & 6 & 24 & B : 11-15 menit \\
\cline { 2 - 5 } & $\mathrm{C}$ & 14 & 56 & C : > 15 menit \\
\hline \multirow{2}{*}{2} & $\mathrm{~A}$ & 7 & 28 & \\
\cline { 2 - 5 } & $\mathrm{B}$ & 7 & 28 & \\
\hline \multirow{2}{*}{3} & $\mathrm{C}$ & 11 & 44 & \\
\cline { 2 - 5 } & $\mathrm{A}$ & 6 & 24 & \\
\cline { 2 - 5 } & $\mathrm{B}$ & 9 & 36 & \\
\cline { 2 - 5 } & $\mathrm{C}$ & 10 & 40 & \\
\hline
\end{tabular}

Dari tabel di atas menunjukkan bahwa kecepatan rata-rata siswa dalam menyelesaikan soal dalam kategori waktu $\mathrm{A}(\square 10$ menit $)$ hanya mencapai $24 \%$, pada kategori $\mathrm{B}(11-15$ menit $)$ berkisar 29,33\%, sedangkan pada kategori C (>15 menit) berkisar 46,67\%. Ini menggambarkan bahwa keterampilan siswa dalam menyelesaikan soal cerita masih sangat kurang dan berkisar $72 \%$ dari jumlah siswa yang tidak mencapai nilai KKM. Hal inilah yang mendorong penulis untuk mengkondisikan para siswa agar menggunakan langkah-langkah prosedural, urut dan sistematis sebagaimana dianjurkan George Polya guna meningkatkan keterampilan siswa dalam menyelesaikan soal cerita pada sistem persamaan linear dua variabel.

1. Hasil Penelitian Siklus 1

Penelitian tindakan kelas ini terlaksana dalam dua siklus. Masing- masing siklus terdiri atas empat tahap yaitu tahap perencanaan, tahap pelaksanaan tindakan, tahap pengamatan dan tahap refleksi. Setelah pelaksanaan siklus 1 diperoleh dua hasil yaitu : 1) Pencapaian alokasi waktu untuk mengetahui tingkat keterampilan siswa dalam menyelesaikan tes akhir siklus, 2) hasil perolehan nilai untuk mengetahui tingkat ketuntasan belajar (pencapaian kriteria ketuntasan minimal/KKM). Adapun rekapitulasi hasil kegiatan pada siklus I dapat disajikan dalam tabel sebagai berikut:

Tabel 3. Pencapaian Alokasi Waktu (tingkat keterampilan siswa dalam menyelesaikan soal berdasarkan alokasi waktu)

\begin{tabular}{|c|c|c|c|l|}
\hline No. Soal & Alokasi Waktu & Banyak siswa & Persentase & Keterangan \\
\hline \multirow{2}{*}{1} & A & 12 & 48 & A : $\square 10$ menit \\
\cline { 2 - 5 } & B & 2 & 8 & B : 11-15 menit \\
\cline { 2 - 5 } & C & 11 & 44 & C :>15 menit \\
\hline 2 & A & 13 & 52 & \\
\hline
\end{tabular}




\begin{tabular}{|c|c|c|c|c|}
\cline { 2 - 5 } \multicolumn{1}{c|}{} & B & 3 & 12 & \\
\cline { 2 - 5 } & C & 9 & 36 & \\
\hline 3 & A & 6 & 24 & \\
\cline { 2 - 5 } & B & 6 & 24 & \\
\cline { 2 - 5 } & C & 13 & 52 & \\
\hline
\end{tabular}

Tabel 4. Perolehan Nilai Tes Siswa

a. Nilai hasil tes pra siklus

\begin{tabular}{r|c|c}
\hline Nilai & Banyak Siswa & Persentase Ketuntasan \\
\hline$\square 65$ & 7 & 28 \\
\hline$\square 65$ & 18 & 72 \\
\hline
\end{tabular}

b. Nilai hasil tes akhir siklus 1

\begin{tabular}{c|c|c}
\hline Nilai & Banyak Siswa & Persentase Ketuntasan \\
\hline$\square 65$ & 10 & 40 \\
\hline$\square 65$ & 15 & 60 \\
\hline
\end{tabular}

Pada pelaksanaan siklus I, aktivitas siswa dalam mengikuti pembelajaran cukup baik yaitu meliputi kehadiran, mengerjakan tugas individu/kelompok, namun keberanian bertanya, mempresentasikan ke depan kelas, maupun menanggapi pekerjaan teman masih perlu ditingkatkan.

Berdasarkan data di atas dapat dilihat bahwa secara umum keterampilan siswa dalam menyelesaikan soal belum maksimal. Rata-rata kecepatan siswa dalam menyelesaikan soal pada kategori $\mathrm{A}(\square 10$ menit) berkisar $41,33 \%$, pada kategori $\mathrm{B}(11-15$ menit $)$ berkisar 14,67 $\%$ dan pada kategori C(> 15 menit) berkisar $44 \%$. Sedangkan pada perolehan hasil tes, pada pra siklus berkisar $28 \%$ yang memiliki nilai tuntas dan ketidaktuntasan mencapai $72 \%$, namun setelah diberikan tindakan pada siklus 1 maka nilai tes akhir siklus 1 ketuntasan pembelajaran mengalami peningkatan yaitu mencapai $40 \%$, sedangkan yang tidak tuntas berkisar $60 \%$. Dengan melihat hasil pelaksanaan siklus I, maka dilakukan refleksi sebagai berikut: a) Perlunya peningkatan bimbingan dan motivasi belajar, b) Perlunya peningkatan keberanian mengemukakan pendapat, c) Sebagian siswa masih bingung menjalankan langkah Polya, terutama dalam menyusun rencana penyelesaian soal, d) Guru diharapkan meningkatkan bimbingan kepada siswa tentang bagaimana memahami soal cerita, menuliskannya dalam kalimat matematika dan menyelesaikannya dengan terampil, e) Terdapat beberapa siswa yang tidak menggunakan langkah keempat yaitu memeriksa kembali hasil yang diperoleh. Perlu penekanan kembali tentang pentingnya langkah ini sehingga dapat meminimalkan kesalahan.

Pelaksanaan kegiatan siklus I berjalan lancar sesuai rencana, namun perlu diperbaiki lagi kekurangan yang terjadi sehingga pada pelaksanaan siklus II dapat memperoleh hasil yang lebih optimal.

2. Hasil Penelitian pada Siklus II.

Setelah memperhatikan kekurangan pada pelaksanaan siklus I dan melakukan perbaikan pada pelaksanaan siklus II, diperoleh hasil sebagaimana tersaji pada tabel berikut ini:

Tabel 5. Pencapaian Alokasi Waktu

\begin{tabular}{|c|c|c|c|l|}
\hline No. Soal & Alokasi Waktu & Banyak siswa & Persentase & \multicolumn{1}{|c|}{ Keterangan } \\
\hline \multirow{3}{*}{1} & A & 17 & 68 & A : $\square 10$ menit \\
\cline { 2 - 5 } & B & 6 & 24 & B : 11-15 menit \\
\cline { 2 - 5 } & C & 2 & 8 & C : > 15 menit \\
\hline
\end{tabular}




\begin{tabular}{|c|c|c|c|c|}
\hline \multirow{3}{*}{2} & A & 16 & 64 & \\
\cline { 2 - 5 } & B & 7 & 28 & \\
\cline { 2 - 5 } & C & 2 & 8 & \\
\hline \multirow{3}{*}{3} & A & 6 & 24 & \\
\cline { 2 - 5 } & B & 9 & 36 & \\
\cline { 2 - 5 } & C & 10 & 40 & \\
\hline
\end{tabular}

Tabel 6. Perolehan hasil Tes Akhir Siklus II.

\begin{tabular}{|c|c|c|}
\hline Nilai & Banyak Siswa & Persentase Ketuntasan \\
\hline$\square 65$ & 19 & 76 \\
\hline$\square 65$ & 6 & 24 \\
\hline
\end{tabular}

Pada pelaksanaan siklus II, aktivitas siswa dalam mengikuti pembelajaran mengalami peningkatan yakni meliputi aktivitas mengerjakan tugas individu/kelompok, keberanian bertanya dan mengemukakan pendapat, mempresentasikan hasil kerja ke depan kelas, maupun menanggapi pekerjaan teman lainnya.

Berdasarkan data di atas dapat dilihat bahwa keterampilan siswa dalam menyelesaikan soal mengalami peningkatan. Kecepatan menyelesaikan soal pada kategori $\mathrm{A}(\square 10$ menit) mencapai $52 \%$, pada kategori $\mathrm{B}(11-15$ menit $)$ mencapai $29,33 \%$ dan kategori $\mathrm{C}(>15$ menit $)$ mencapai $18,67 \%$ Sedangkan untuk perolehan hasil tes akhir siklus menunjukkan peningkatan yakni mencapai $76 \%$.

\section{B. Pembahasan}

Berdasarkan hasil siklus I dan data observasi siswa pada siklus I diperoleh bahwa masih terdapat siswa yang mengerjakan soal dengan langkah Polya yang tidak lengkap Masalah ini dikarenakan mereka mengalami kesulitan dalam memahami soal. Faktor yang memungkinkan menjadi penyebab kesulitan siswa adalah pemahaman atau penguasaan bahasa masih sangat kurang. Jika siswa dapat memahami maksud soal, maka mereka dapat menangkap pesan soal kemudian menyusun rencana untuk menyelesaikan selanjutnya menyelesaikan soal dengan cepat/terampil. Hal ini mengandung arti bahwa pemahaman maksud soal sangat menentukan langkah pengerjaan selanjutnya dan mempengaruhi tingkat keterampilan siswa dalam mengerjakan soal.

Untuk mengungkap keterampilan siswa dalam menyelesaikan soal soal cerita maka dibuat skor pencapaian waktu dan skor nilai. Dari gabungan kedua skor tersebut dapat diketahui tingkat keterampilan siswa dalam menyelesaikan setiap soal. Sesuai dengan data siklus I diperoleh tingkat keterampilan siswa dalam menyelesaikan soal-soal yang diberikan adalah sebesar $45 \%$ dan ketuntasan belajar tercapai $40 \%$.Setelah melakukan refleksi siklus I dan pembenahannya selanjutnya dilaksanakan siklus II. Pada siklus II ini kemampuan siswa dalam menyelesaikan soal cerita dengan menggunakan langkah Polya pada umumnya sudah meningkat. Hal ini terlihat dari hasil pekerjaan siswa yang tersusun secara urut dan sistematis, kesalahan pada siklus I tidak terulang lagi. Hasil akhir siklus II diperoleh tingkat keterampilan siswa dalam menyelesaikan soal cerita dengan langkah Polya adalah sebesar 75,0 \%, terjadi 
peningkatan sebesar $30 \%$ dan ketuntasan belajar mencapai $76 \%$ terjadi peningkatan sebesar

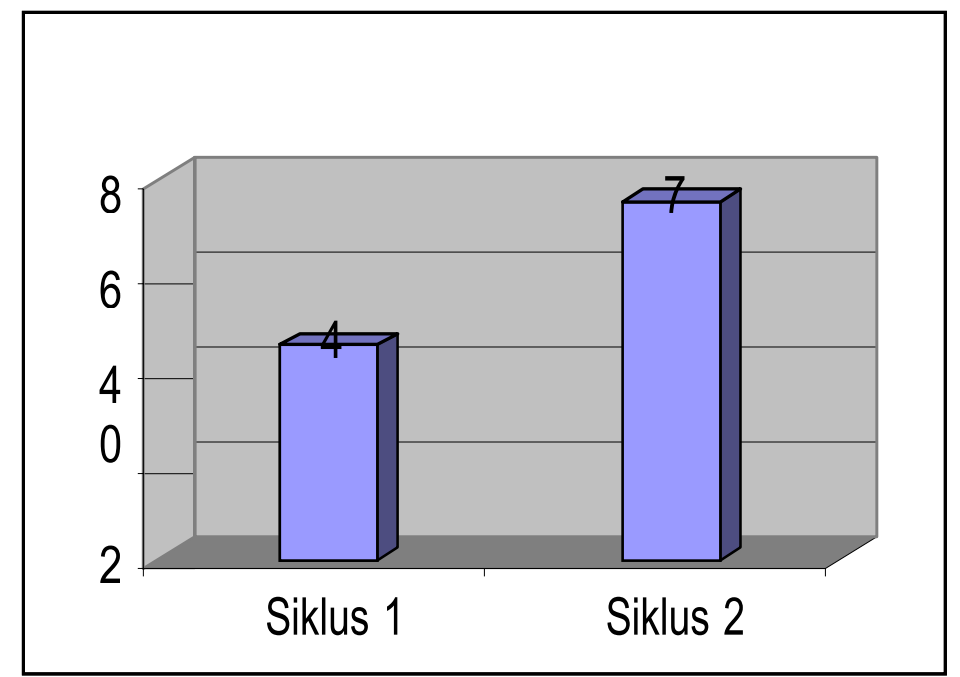

35\%. Data diatas dapat disajikan dalam bentuk diagram sebagai berikut :

Gambar 1. Persentase keterampilan siswa

Dari diagram di atas mendeskripsikan bahwa pada siklus 1 tingkat keterampilan siswa dalam menyelesaikan soal cerita hanya mencapai $45 \%$, namun setelah diberikan tes diakhir siklus 2 maka tingkat keterampilan siswa untuk menyelesaikan soal cerita meningkat menjadi $75 \%$, hal ini menunjukkan bahwa ada peningkatan yang signifikan setelah dilakukan tindakan pada siklus 2. Dari hasil pelaksanaan siklus I dan II diperoleh bahwa dengan menggunakan langkah Polya, siswa dapat menyelesaikan soal cerita pada materi persamaan linear dua variabel dengan cepat dan meningkat.

1. Penelitian yang relevan

Penelitian Kurniasari, I yang berjudul "Kefektifan Model Pembelajaran MMP dengan langkah Pemecahan Masalah Polya terhadap Kemampuan Kreatifitas Kelas VII" menyatakan bahwa Pemecahan masalah Polya efektif dalam meningkatkan kreativitas siswa meningkatkan kerjasama siswa dalam kelompok".

Penelitian Wibisono yang berjudul "Metode Penggunaan Langkah Polya Untuk Meningkatkan Keterampilan Menyelesaikan Soal Cerita Materi Sistem Persamaan Linear Dua Variabel Pada Siswa Kelas X IPA-1 SMA Negeri 26 Jakarta" menyatakan bahwa "Melalui penggunaan langkah Polya, keterampilan siswa dalam menyelesaikan soal cerita pada materi sistem persamaan linear dua variabel dapat ditingkatkan.

Penelitian Putri dkk yang berjudul "Penerapan Langkah-Langkah Polya untuk Meningkatkan Hasil Belajar Siswa pada Materi Soal Cerita Sistem Persamaan Linear Dua Variabel di Kelas VIII SMP Negeri 19 Palu" menyatakan bahwa "penerapan langkah-langkah Polya dapat meningkatkan hasil belajar siswa pada materi sistem persamaan linear dua variabel di kelas VIII SMP Negeri 19 Palu melalui beberapa langkah yaitu: (1) memahami masalah, (2) membuat perencanaan, (3) melaksanakan perencanaan dan (4) melakukan pengecekkan kembali dari hasil yang diperoleh".

Penelitian Fevi Angraeni yang berjudul " Penerapan Metode Polya Untuk Meningkatkan Hasil Belajar Siswa Kelas X TSM SMK Negeri 1 Parigi Dalam Menyelesaikan Masalah Soal Cerita Sistem Persamaan Linear Dua Variabel" menyimpulkan bahwa "setelah dilakukan tindakan dengan beberapa kali perbaikan dari refleksi siklus I maka hasil belajar pada siklus II mengalami peningkatan, ini membuktikan bahwa penerapan metode Polya dalam menyelesaikan soal cerita SPLDV dapat meningkatkan hasil belajar siswa SMK Teknik Sepeda Motor SMK Negeri 1 Parigi”.

Dengan demikian, berdasarkan kesimpulan para peneliti yang relevan dan hasil data yang diperoleh, maka dapat dikatakan bahwa penggunaan langkah Polya dalam menyelesaian soal cerita pada sistem persamaan linear dua variabel dapat meningkatkan Keterampilan Siswa 
kelas VIII.C SMP Negeri 02 Rumbia Tahun Pelajaran 2020/2021.

\section{KESIMPULAN}

berikut :

Berdasarkan hasil penelitian dan pembahasan, maka dapat disimpulkan sebagai

1. Kemampuan menyelesaikan soal cerita matematika setelah diterapkan langkah polya pada materi sistem persamaan linear dua variabel mengalami peningkatan. Rata-rata tes keterampilan pada siklus I sebesar $45 \%$ dan siklus II sebesar $75 \%$ dengan kategori sangat baik.

2. Ketuntasan belajar siswa pada siklus 1 berkisar $40 \%$ dan siklus 2 meningkat menjadi $76 \%$

3. Keterlaksanaan pembelajaran guru saat penerapan langkah polya untuk setiap siklusnya berada pada kategori baik

4. Aktivitas siswa pada saat penerapan langkah polya adalah baik

5. Respon siswa terhadap penerapan langkah polya adalah positif ditingkatkan dengan menggunakah prosedur polya.

Dengan demikian bahwa penelitian Keterampilan Siswa dalam Menyelesaikan Soal Cerita Pada Materi Persamaan Linear Dua Variabel melalui Langkah Polya dapat ditingkatkan.

\section{DAFTAR PUSTAKA}

Angraeni, Fevi. (2014). Penerapan Metode Polya Untuk Meningkatkan Hasil Belajar Siswa Kelas X TSM SMK Negeri 1 Parigi Dalam Menyelesaikan Masalah Soal Cerita Sistem Persamaan Linear Dua Variabel." Jurnal Kreatif Online 2.4 (2014).

Herlambang. (2013). Analisis Kemampuan Pemecahan Masalah Matematika Siswa Kelas VIIA SMP Negeri 1 Kepahiang tentang Bangun Datar Ditinjau dari Teori Van Hiele. Retrieved from http://repository.unib.ac.id/8426/2/I,II,III,2-13-her.FI.pd

Kurniasari, I, (2014). Kefektifan Model Pembelajaran MMP dengan langkah Pemecahan Masalah Polya terhadap Kemampuan Kreatifitas Kelas VII, Unnes Journal of Mathematis Education

Putri, Resky Yuliani; HAMID, Abdul; MURDIANA, I Nyoman, (2016). Penerapan LangkahLangkah Polya untuk Meningkatkan Hasil Belajar Siswa pada Materi Soal Cerita Sistem Persamaan Linear Dua Variabel di Kelas VIII SMP Negeri 19 Palu. Jurnal Elektronik Pendidikan Matematika Tadulako, 2016, 4.1: 543-557.

Ruseffendi, E. T. (2006). Pengantar Kepada Membantu Guru Mengembangkan Kompetensinya dalam Pengajaran Matematika untuk Meningkatkan CBSA. Bandung: Tarsito. Retrieved from http://onesearch.id/Record/IOS3107.10571

Sabirin, M. (2011). Pengaruh Pembelajaran Berbasis Masalah terhadap Kemampuan Pemecahan Masalah, Komunikasi, dan Representasi Matematis Siswa SMP. Universitas Pendidikan Indonesia. Retrieved from http://repository.upi.edu/8048/

Shadiq, Fadjar. 2004. Penalaran, Pemecahan Masalah dan Komunikasi dalam Pembelajaran Matematika. (Makalah Diklat Instruktur/Pengembang Matematika SMP Jenjang Dasar) PPPG Matematika Yogyakarta.

Wibisono Riptahadi, (2019). Metode Penggunaan Langkah Polya Untuk Meningkatkan Keterampilan Menyelesaikan Soal Cerita Materi Sistem Persamaan Linear Dua Variabel Pada Siswa Kelas X IPA-1 SMA Negeri 26 Jakarta, Madani Institute : Jurnal Politik, Hukum, Ekonomi, Pendidikan dan Sosial-Budaya: Vol. 8 No. 1.

Yuwono, Timbul, Mulya Suoanggih, and Rosita Dwi Ferdiani, (2018). “Analisis Kemampuan Pemecahan Masalah Matematika dalam Menyelesaikan Soal Cerita Berdasarkan Prosedur Polya."Jurnal Tadris Matematika 1. 2 